\title{
Pollen-ovule relation in Adesmia tristis and reflections on the seed-ovule ratio by interaction with pollinators in two vertical strata
}

\author{
NADILSON R. FERREIRA ${ }^{1}$, LUCIA B. FRANKE ${ }^{1}$ and BETINA BLOCHTEIN ${ }^{2}$ \\ ${ }^{1}$ Departamento de Plantas Forrageiras e Agrometeorologia, Faculdade de Agronomia, \\ Universidade Federal do Rio Grande do Sul, Av. Bento Gonçalves, \\ 7712, 91501-970 Porto Alegre, RS, Brasil \\ ${ }^{2}$ Faculdade de Biociências, Universidade Católica do Rio Grande do Sul, \\ Instituto do Meio Ambiente e dos Recursos Naturais, \\ Av. Ipiranga, 6681, Partenon, 90619-900 Porto Alegre, RS, Brasil
}

Manuscript received on May 27, 2013; accepted for publication on November 1, 2013

\begin{abstract}
The vertical distribution of pollinators is an important component in the foraging pattern of plants strata, and it influences the reproductive system (pollen/ovule ratio) and seed/ovule ratio. Niches in two different strata from Adesmia tristis Vogel were evaluated in these aspects. This plant is an endemic shrub from the Campos de Cima da Serra in Southern Brazil. The studies were carried out from January 2010, to January 2011, at Pró-Mata/PUCRS (Catholic University of Rio Grande do Sul) (29 $27^{\prime}-29^{\circ} 35^{\prime}$ S and $50^{\circ} 08^{\prime}-50^{\circ} 15^{\prime} \mathrm{W}$ ), São Francisco de Paula, sate of Rio Grande do Sul, Brazil. Breeding system of $A$. tristis is mandatory allogamy. The vertical profile in A. tristis has differentiated foraging niches among the most common pollinators. Bees of Megachile genus forage in the upper stratum, and representative bees of the Andrenidae family explore the lower stratum. The upper stratum of the vertical profile had more contribution to seed production. Adesmia tristis showed evidence of pollination deficit.
\end{abstract}

Key words: allogamy, bees, foraging, niches, pollination deficit.

\section{INTRODUCTION}

The vertical distribution of pollinators is an important component associated with the foraging pattern in different strata of a plant (Roubik et al. 1995). It is linked to selective effects of vegetation structure, distribution of plants inflorescences, and profile of floral visitors. The relationships among populations of different pollinators in the same vertical gradient can generate different

Correspondence to: Nadilson Roberto Ferreira

E.mail:nr.ferreira@uol.com.br levels of interactions. Competition for resources is an interaction that can induce a population to affect the other one (Menezes et al. 2007, NatesParra et al. 2008, Jha and Vandermeer 2009) even if indirectly. The competitive interaction on a time scale foments an ecological separation among related species leading to the principle of competitive exclusion. This fact promotes selective adaptations that facilitate coexistence of organisms' diversity in habitats (Odum 1988), regardless of the environmental scale. It is possible that a 
similar process may have occurred with Adesmia tristis Vogel. This is an endemic leguminous plant belonging to the physiographic region of Campos de Cima da Serra, in Southern Brazil.

It has a high forage potential (Overbeck et al. 2007) and wide ecological distribution. Adesmia tristis is a shrub found in altitudes between 500 to $1300 \mathrm{~m}$, with ascending decumbent growth habit. Its branches may reach $1.5 \mathrm{~m}$ in length (Miotto and Leitão Filho 1993). Reaching $0.70 \mathrm{~m}$ after initial ascendancy, the branches have the tendency to be decumbent due to their own weight. In tipping, the branches are supported by the surrounding vegetation, forming a profile with variable height.

Inflorescence is massive and composed by simple racemes multiflorus laxiforus. Flowering occurs from October to April, with peaks from December to January (Miotto and Leitão Filho 1993). The main pollinators of Adesmia are the solitary bees represented byAndrenidae, Apidae, Coletidae, and Megachilidae (Chiappa et al. 2000, Camacho and Franke 2008, Forcone and Muñoz 2009, Smith-Ramírez and Ramírez 2010).

As it is a wild plant, the knowledge of the interactions of A.tristis with pollinators and the type of reproductive system is crucial, as well as studies on such species, to asses flow and subsequent genotypic frequencies (Hamrick and Godt 1990).

The use of pollen/ovule $(\mathrm{P} / \mathrm{O})$ relation as a tool to assess the reproductive processes in plants is characterized by being skillful and precise, with reduced costs when faced with thecniques of molecular markers or crossing (Cruden 2000).

Combining knowledge on reproductive system with interactions would be useful in careful managements to conserve the species in Campos de Cima da Serra. Therefore, this study was carried out in order:

1. To evaluate the pollen/ovule relation on reproductive system of $A$. tristis.

2. To compare the seed/ovule under the influence of two groups fo bees with differentiated niches in vertical profile in $A$. tristis.

3. To evaluate seed/ovule index in A. tristis.

\section{MATERIALS AND METHODS}

The study was carried out from January 2010, to January 2011, at Centre for Research and Conservation of Nature - Catholic University of Rio Grande do Sul, Brazil, 29 $27^{\circ}-29^{\circ} 35^{\prime} \mathrm{S}$ and $50^{\circ} 08^{\prime}-$ $50^{\circ} 15^{\prime} \mathrm{W}$ (Bertoletti and Teixeira 1995) (Fig. 1). This area is located on the region of the Araucária Plateau in the municipality of São Francisco de Paula, sate of Rio Grande do Sul, Brazil. The altitude ranges from 600 to $900 \mathrm{~m}$, and the climate is classified as Köppen's $\mathrm{Cfb}$, temperate maritime humid with average annual temperature of $14.5^{\circ} \mathrm{C}$ and frequent formation of fog, frost, and occasional snow (Dick et al. 2008, Almeida 2009). Average annual rainfall is $2252 \mathrm{~mm}$, well distributed over the year (Bertoletti and Teixeira 1995, Bond-Buckup 2008). The site soil is classified as Bruno Cambisol soil. The main features being humic and alic properties (Bertoletti and Teixeira 1995), with high acidity ( $\mathrm{pH} 4.0)$ and low in phosphorus $(3.1 \mathrm{mg} /$ $\mathrm{dm}^{3}$ ), according to result of soil analysis carried out in May 2008, by the Department of Lands/UFRGS (Federal University of Rio Grande do Sul), Brazil, and supporting vegetation characterized as natural grasslands. The cultivated $A$. tristis population at the study site harboured 1,800 plants in $450 \mathrm{~m}^{2}$.

Pollen/ovule relation was studied to characterize the reproductive system of $A$. tristis, (Cruden 1977 2000). In this process, the number of ovules per ovary and the number of pollen grains per flower were quantified. Randomly, 30 flower buds at pre-anthesis stage were collected to determine the average number of ovules per ovary. Ovules were counted under a stereoscopic microscope. For the counting of the pollen grains by flower, the method of exotic marker with spores of Lycopodium clavatum contained in pellet with 18,584 spores (Stockmarr 1971) was used.

This method is based on estimates from adding known number of spores that are associated with the count of the pollen grains present in the sample. 

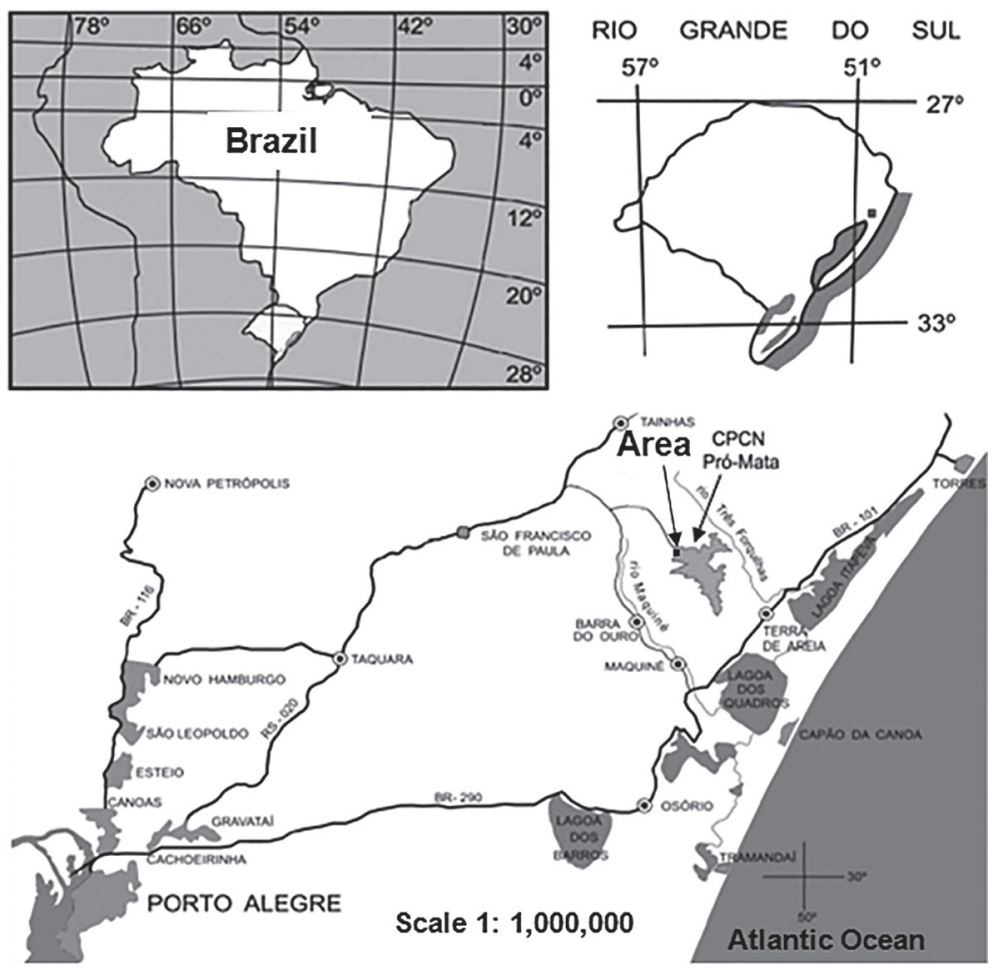

Fig. 1 - Territory of the Centre for Research and Conservation of Nature (PróMata), RS, Brazil, where the study was carried out (Adapted from Bertolleti and Texeira 1995).

During the process of counting pollen, spores are also counted, and the latter was used to estimate the pollen concentration of the analyzed material. For this process, 10 flower buds in pre-anthesis stage were collected randomly, whose anthers had been dismembered.

Pollen grains were separated with stilettos, tweezers, Petri dish, pipette, and $7.0 \mathrm{~mL}$ of distilled water for washing. After this procedure, the pollen grains of each flower were placed in an ependdorf tube of $1.5 \mathrm{~mL}$, adding the pastille of $L$. clavatum previously diluted in water. The 10 ependdorf tubes were centrifuged at 2,000 rpm for five minutes and the supernatant discarded. Subsequently, three slides were prepared per ependdorf tube using glycerinated gelatin, and stained with fuchsine. A small amount of gelatin was poured into the eppendorf tube to collect the precipitate, which contained the pollen grains. The gelatin with adhered grains was placed onto a slide heated by a alcohol lamps, covered with coverslip and sealed with transparent enamel (Louveaux et al. 1978). The counting of pollen grains and spores was performed using an optical microscope, scanning the whole blade. From the results, the number of pollen per flower $(\mathrm{P})$ was estimated by the equation $\mathrm{P}=18,584 \mathrm{p} / \mathrm{L} ; \mathrm{p}$ and $\mathrm{L}$ were the readings of pollen grains and spores of $L$. clavatum per blade, respectively. The averages of pollen/ovule relation were grouped according to classification of Cruden (1977): “cleistogamy $(<5.4)$; mandatory autogamy (5.5 to 39); optional autogamy (39.1 to 396.9); facultative allogamy (397-2,588); and mandatory allogamy $(>2,588)$ ".

To study the difference of seed/ovule relation between the two groups of bees with different niches in $A$. tristis, two strata of the vertical profile of approximately $70 \mathrm{~cm}$ in height were demarcated. 
The lower stratum was marked up to about $30 \mathrm{~cm}$ in height from the ground level, and the upper stratum comprised a layer of $30 \mathrm{~cm}$ from the canopy level to downward, leaving an interface between them of $10 \mathrm{~cm}$ (Fig. 2). For each stratum, 10 racemes with average length of $20 \mathrm{~cm}$ measured from the apex were collected. For each raceme, the number of flower buds and the number of flowers, and the estimate of future aborted flowers and future seeds based on the allogamy rate or effective pollination, were quantified.

This rate was obtained by demarcating 300 flower buds in pre-anthesis stage, with free pollinators visitation and subsequent counting of formed hemicraspedious expressed as percentage; aborted flowers; ovule per ovary; hemicraspedious fruits in raceme and already released by the plant; seeds by hemicraspedious fruits (offspring potential); estimate of seeds released by plant; estimate of total seed; estimate of total ovule; and estimate of seed/ovule ( $\mathrm{S} / \mathrm{O})$ ratio".

Regarding the number of ovules, randomly 30 flower buds in pre-anthesis stage were collected from each stratum, following the same methodology previously described (in pollen/ovule relation). The values were expressed by mean with standard errors. The variances of $\mathrm{S} / \mathrm{O}$ relation of the two strata were compared by Snedecor F test to evaluate the homoscedasticity and define the appropriate statistics for comparing the means by Student's t test with $1 \%$ probability.

Adesmia tristis has a massive flourishing involving the entire vertical profile of the plant, being composed by a complex structure of interlocking branches not only from the same plant but also from its neighbours. In this context, is very important to observe different levels in the vertical profile linked to different kind of pollinators. In order to survey the frequency, four period of 30 minutes per day were used (9:00 h, 12:00 h, 14:00 h, 16:00 h) during nine days. Parallelly to this activity, the time of visiting per flower was recorded during eight hours.

Surveying the seeds and ovules generates an index when using $\mathrm{S} / \mathrm{O}$ relation. This index is inversely proportional to pollination deficit. The range extends from 0 to1, which represents a gradient, from the complete absence of seeds until the maximum potenctial of seeds production.

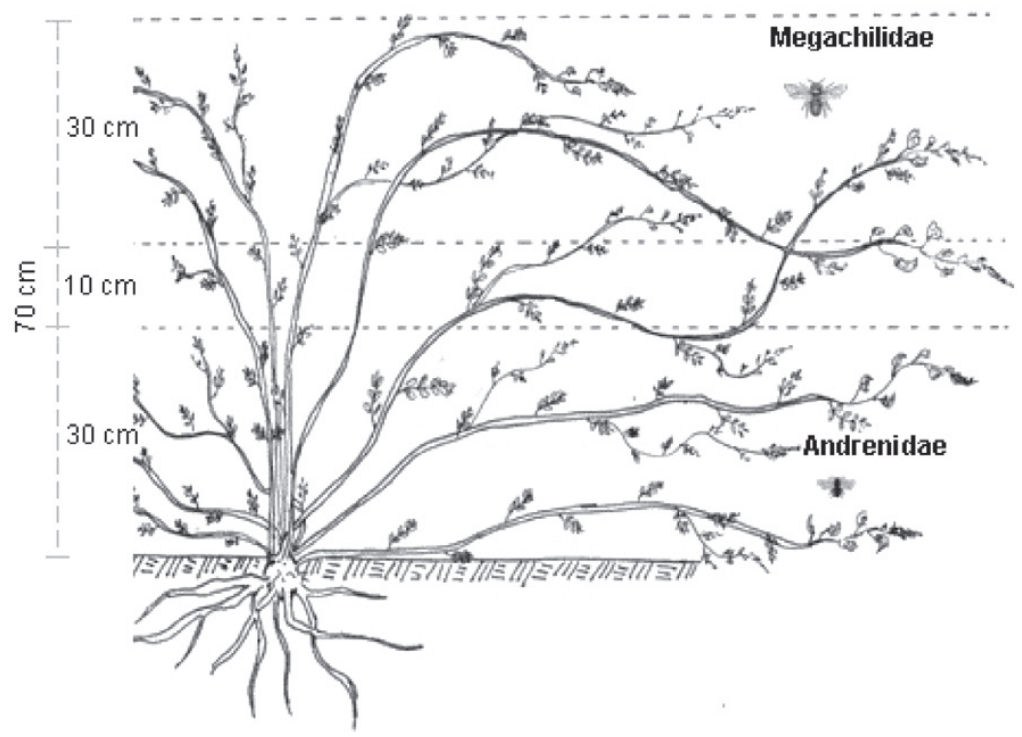

Fig. 2 - Schematic drawing of the vertical profile in Adesmia tristis with the subdivision of two strata and boundary range, and the localization of the two most common groups of pollinators (Megachilidae and Andrenidae). 


\section{RESULTS}

Adesmia tristis showed $5.07 \pm 0.58$ ovules per ovary and $30.350 \pm 5.511$ pollen grains per flower. As a result, pollen/ovule $(\mathrm{P} / \mathrm{O})$ relation was 6,026.6.

The two most common groups of pollinators in A. tristis are solitary bees belonging to Megachilidae and Andrenidae families. These bees are fundamental to the reproductive system in A. tristis; nevertheless, high incidence of aborted flowers was observed. In this study, allogamy rate was $37 \%$. Data comprising the two studied strata showed that there is equivalence in total of aborted flowers (TAF) and the number of seeds per hemicraspedious fruits $(\mathrm{S} / \mathrm{H})$ in both strata (Table I). However, statistical differences were highly significant $(\mathrm{p}<0.01)$ in the total number of hemicraspedious fruits $(\mathrm{TH})$ (hemicraspedious fruits in raceme and hemicraspedious fruits already released by plant), in the total number of seeds (TS), in the seed/ ovule $(\mathrm{S} / \mathrm{O})$ relation, and significant difference in the total number of ovules (TO) $(\mathrm{p}<0.05)$ (Table I). In the two strata, the number of formed seed $(9.5 \%$ and $5.2 \%$ in the upper and lower strata, respectively) is less than the number of available ovules for fertilization, and the difference is higher in the lower stratum (Fig. 3).

Regarding pollination efficiency in the flower scope, the two groups of bees are equivalent; hence, the number of seeds/hemicraspedious fruits is statistically equal (Table I). However, bees from Megachile genus are more agile ( $2.5 \pm 0.4$ seconds/flower) in the flower blooming phase when compared with Andrenidae group ( $6.4 \pm 0.9$ seconds/flower), visiting more flowers per time unit. This fact reflects a higher seed production on the upper stratum with proportional consequences in $\mathrm{S} / \mathrm{O}$ relation (Fig. 4). It is noteworthy that the flowers of the lower stratum had fewer ovules (4.8/ovary) in relation to the higher stratum (5.3/ovary) and this difference was statistically significant $(\mathrm{p}<0.01)$ (Table I).

Data obtained in A. tristis showed the $\mathrm{S} / \mathrm{O}$ relation of 0.1 and 0.05 in the upper and lower strata, respectively, and the offspring potential $(\mathrm{S} / \mathrm{H})$ of 3.23 (Table I) show that values are linked to factors of pollination deficit.

\section{DISCUSSION}

The reproductive system that characterizes $A$. tristis is mandatory allogamy $(\mathrm{P} / \mathrm{O}>2,588)$ according to Cruden classification (1977). It is similar to results found in 15 species of Adesmia genus with treatment of mutual pollination and mechanical stimulus (Tedesco et al. 2000). These authors concluded that A. tristis depends on cross-pollination, with possible occurrence of incompatibility mechanisms. The same conclusion was obtained with plants of $A$. latifolia isolated by screens, resulting in the absence of seed set formation (Camacho and Franke 2008).

Allogamy, case of A. tristis, enables hybrid vigor, facilitating the maintenance of species in the environment. It is interesting that the number of viable pollen grains is sufficient for the promotion of heterozygosity (Souza et al. 2002), avoiding mitigating effects on pollinator capability (Cruden 2000). Pollinators when conducting the pollen to the corresponding stigma minimize the loss risks (Cocucci and Mariath 2004), directly influencing the plant reproductive system. Therefore, the more efficiently pollen grains reach the compatible stigma, the greater the fertilization opportunities with low $\mathrm{P} / \mathrm{O}$ relation.

Frequent winds, rainfalls, and fog in the studied area reduced pollinators' activity, which, together with intrinsic plant characteristics affected allogamy rate, also known as natural crossing rates with consequent low seed production. It is necessary to preserve and stimulate the increase of local pollinator populations using responsible practices in areas managed by men and establishing protected environments, thereby preventing the risk of reducing pollen grain flow and consequently, production (Lennartsson 2002, Kolb 2005, Freitas et al. 2010), rendering the species non-viable in the environment (Nayak and Davidar 2010).

Natural branches arrangement restricts pollinators circulation spaces of pollinators seeking target flowers descending from the canopy to the ground. Differentiated niches or micromosaics 
TABLE I

Means of parameters measured and estimated at 10 racemes of Adesmia tristis for each one of the two strata of the plant vertical profile, as follows: "RA - raceme; $\mathrm{U}$ - upper stratum; L - lower stratum; TAF- total aborted flowers; O/O - ovule per ovary $(n=30)$; S/H - seeds per hemicraspedious fruits; TH - total hemicraspedious fruits; TS - total seeds; TO - total ovules; S/O - seed/ovule relation. Pró-Mata PUCRS, São Francisco de Paula, RS, January 2010 and 2011 ”.

\begin{tabular}{cccccccc}
\hline RA & TAF & O/O & S/H & TH & TS & TO & S/O \\
\hline $\mathrm{U}$ & $134.61 \mathrm{a}$ & $5.30 \mathrm{a}$ & $3.23 \mathrm{a}$ & $24.60 \mathrm{a}$ & $79.53 \mathrm{a}$ & $841.57 \mathrm{a}$ & $0.10 \mathrm{a}$ \\
$\mathrm{L}$ & $131.37 \mathrm{a}$ & $4.80 \mathrm{~b}$ & $3.22 \mathrm{a}$ & $10.90 \mathrm{~b}$ & $35.38 \mathrm{~b}$ & $680.00 \mathrm{~b}$ & $0.05 \mathrm{~b}$ \\
\hline
\end{tabular}

Means followed by the same letter vertically are not statistically different from each other by Student's t test at $1 \%$ of probability. In TO comparison, the test was $5 \%$.

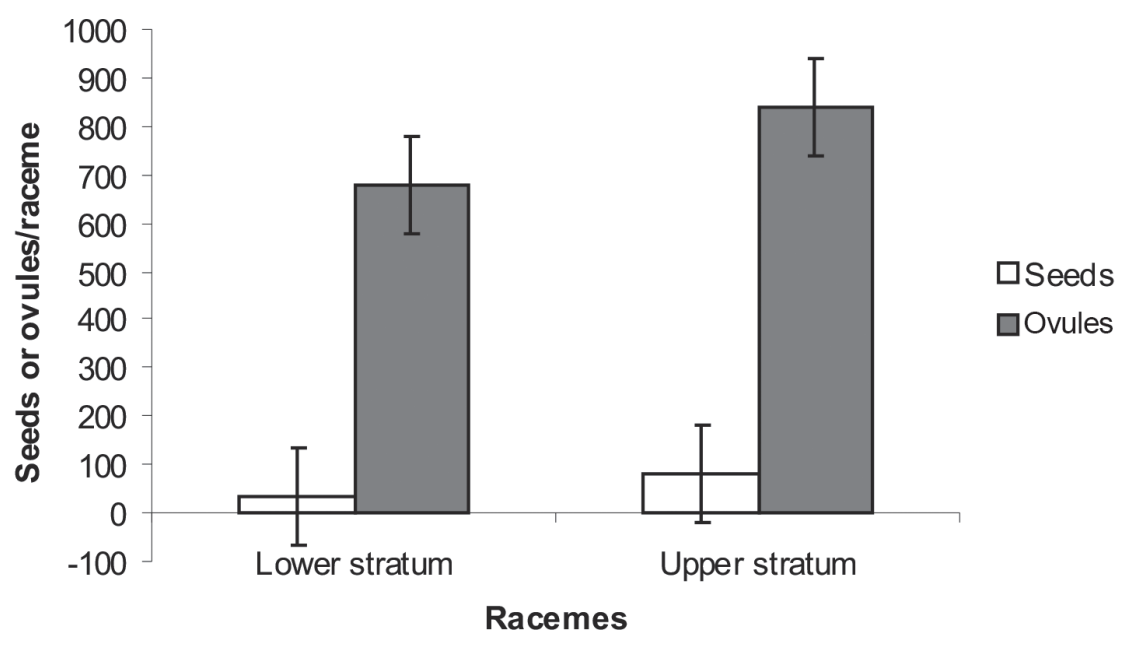

Fig. 3 - Average number of seeds and ovules formed in 10 racemes of $A$. tristis lower and upper strata with standard error bars.

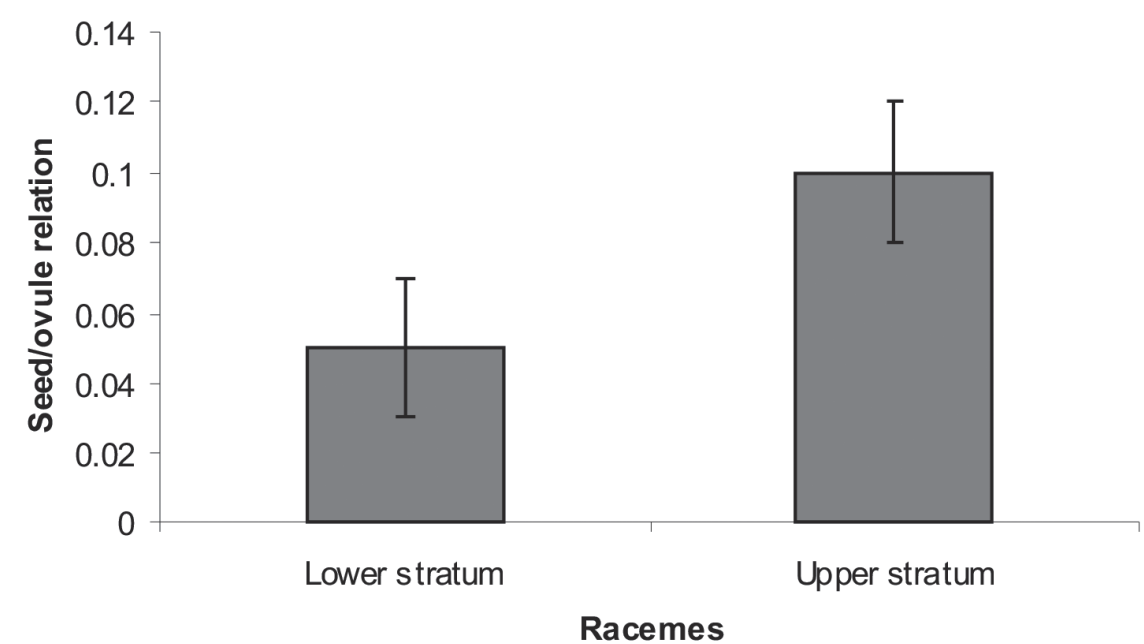

Fig. 4 - Seed/ovule relation of racemes from Adesmia tristis lower and upper strata with standard error bars. 
of foraging are formed in plant's vertical profile. However, the magnitude of these trophic niches is subject to temporal and spatial changes (Aguiar and Santos 2007) because they are linked to the structure of the surrounding vegetation.

The two most common pollinator groups in A. tristis have distinct characteristics. Bees of Megachilidae family are robust and fast compared with bees of Andrenidae family. The first ones preferentially visit flowers of the plant's upper stratum near the canopy with more free space for their evolutions in searching nectar and pollen. The other ones are more common in the lower stratum. It is assumed that these characteristics facilitated the formation of ecological niches associated with the principle of competitive exclusion (Odum 1988). These adaptations are selective and allow the coexistence of organism's diversity in habitats (Chesson 1991, 2000, Giacomini 2007).

In $A$. tristis, the competition involves not only nectar and pollen, but particularly space. Sometimes, bees belonging to the Andrenidae family were observed foraging in the upper stratum, and when bees from Megachilidae family arrived, there was some disagreement and the smaller ones (Andrenidae) migrated to the lower stratum. This Behaviour occurs because bees from both families visit $A$. tristis flowers at the same time of the day. Some studies report the coexistence of bee species in the same plant, using different foraging strategies (Morgado et al. 2002, El Shafie and Mogga 2002, Biesmeijer and Slaa 2006, Carvalho and Oliveira 2010). This aspect is convenient in A. tristis by pollination complementation, with direct impact on seed production and species perpetuation. Thus, a pollinators' guild is more effective for the pollination service and system stability than a single species (Hoehn et al. 2008).

Low seed yield in the two strata below the ovules to be fertilized means there are pollination deficit problems.

It is possible that the pollinators' population of $A$. tristis were decreased, contributing to the high incidence of flowers capable of forming hemicraspedious fruits that aborted. The massive supply of flowers outside the natural patterns (plantation) must have exceeded the capacity of pollinator visits. The massive flowering (in time and space) should also be considered as adaptive strategy in reproductive success (Inouye 2008). In nature, the cross-pollinated plants normally do not reach the maximum production level of fruit and/or seeds (Barrett 2002). The pollination deficit with its levels gradations is an environmental standard. A survey in Canada with 258 species of angiosperms showed a maximum limit of $45 \%$ of effective pollination in seed production (Burd 1994). Genetic factors are possible causes of flowers abortion, according to the development of homozygous embryos for deleterious alleles (Charlesworth 1989). Other interferences such as the limitation of resources affect flowering process (Weins 1984, Griffin and Barrett 2002). In A. tristis, such factors and circumstances may be involved. The possible occurrence of geitonogamy may cause selfincompatibility (Tedesco et al. 2000). This induces the decrease of desirable pollen flow and changes in the target stigma. Consequences lead to decrease of crossing process and reduction in female function with lower seed production (Barrett 2002).

The difference among the amount ovules from the two strata demonstrates that other factors affect plant physiology, such as light reception and nutrient translocation in the drain and source operations, and hormonal actions (Larcher 2003, Taiz and Zeiger 2009) act synergistically to enhance branch vigor, increasing the number of seeds in the upper stratum.

The progeny potential of $A$. tristis was 3.23. It relates to the ovule protection, dispersal, and $r$ e $k$ strategies of population growth of Pianka (1970), where $r$ represents opportunistic species, which are usually annual, that most of their energy to reproductive effort; and $k$ represent resourcecompeting species, which are usually perennial, and spends most of their energy for maintenance (Odum 1988). Another value that stands out in the plant under study is $\mathrm{S} / \mathrm{O}$ relation, and 0.10 and 0.05 are for the 
upper and lower strata, respectively. In unchanged environments, $\mathrm{S} / \mathrm{O}$ relation of annual plants is around 0.85 with offspring potential of 21.70 . In perennial plants, $\mathrm{S} / \mathrm{O}$ average is 0.50 , regardless of the reproductive system, and the offspring potential is only 9.90 (Weins 1984). Woody species (k strategy) have lower $\mathrm{S} / \mathrm{O}(0.30)$ ratios and offspring potential (3.30), when compared to perennial herbaceous with S/O of 0.57 and offspring potential of 13.50 (Weins 1984). In Fabaceae, it is common to find low values of fruit/flowers ratio and/or seed/ovules (Bawa and Buckley 1989). Studies on reproductive Biology of Caesalpinia pyramidalis (Fabaceae) in the Caatinga region of Northeastern Brazil showed similar results (Leite and Machado 2009).

Our results indicate that A. tristis presents compulsory allogamy. The vertical profile of the plant has different foraging niches for the most frequent pollinators, where the bees belonging to Megachile genus forage preferentially close to the plant canopy, while bees belonging to Andrenidae family forage in the lower stratum. The upper stratum of the plant vertical profile contributes more to seed production than the lower stratum.

The obtained S/O relation of $A$. tristis suggests the possibility of pollination deficit. However, this index should be associated with other methods of pollination deficit classification, such as those recommended by Food and Agriculture Organization od the United Nacions (FAO), as mentioned by Vaissière et al. (2011), to support conclusions. These results are important for guiding management plans aiming at possible corrections of factors that limit fruits and/or seeds production in order to obtain the expected results.

\section{RESUMO}

A distribuição vertical dos polinizadores é um importante componente no padrão de forrageamento nos estratos das plantas e influencia o sistema reprodutivo (relação pólen/ óvulo) e a razão semente/óvulo. Nichos em dois estratos diferentes de Adesmia tristis Vogel foram avaliados quanto a esses aspectos. Essa planta é um arbusto endêmico dos campos de Cima da Serra no Sul do Brasil. Os estudos ocorreram de janeiro de 2010 a janeiro de 2011, no PróMata/PUCRS (Pontifícia Universidade Católica do Rio Grande do Sul) $\left(29^{\circ} 27^{\prime}-29^{\circ} 35^{\prime} \mathrm{S}\right.$ e $\left.50^{\circ} 08^{\prime}-50^{\circ} 15^{\prime} \mathrm{W}\right)$, São Francisco de Paula, estado do Rio Grande do Sul, Brasil. O sistema reprodutivo de $A$. tristis é alogamia obrigatória. O perfil vertical em A. tristis possui diferentes nichos de forrageamento entre os polinizadores mais comuns. Abelhas do gênero Megachile forrageiam no estrato superior e as abelhas representantes da família Andrenidae exploram o estrato inferior. $\mathrm{O}$ estrato superior do perfil vertical contribui mais na produção de sementes. Adesmia tristis apresentou evidências de déficit de polinização.

Palavras-chave: alogamia, abelhas, forrageamento, nichos, déficit de polinização.

\section{REFERENCES}

Aguiar CML And SAntos GMM. 2007. Compartilhamento de recursos florais por vespas sociais (Hymenoptera: Vespidae) e abelhas (Hymenoptera: Apoidae) em uma área de Caatinga. Neotrop Entomol 38: 836-842.

AlmeIDA JA. 2009. Fatores abióticos. In: BOLDRINI II (Ed), Biodiversidade dos Campos do Planalto das Araucárias, Brasília: MMA, p 21-25.

BARRET SCH. 2002. Sexual interference of the floral kind. Heredity 88: 154-159.

BAWA KS AND BUCKLEY DP. 1989. Seed: ovule rations, selective seed abortation, and mating systems in Leguminosae. In: STIRTON CH AND ZARUCCHI JL (Eds), Advances in legume, St. Louis: Missouri Botanical Garden Press, St. Louis, USA, p. 243-262.

Bertoletti JJ And TeXeIRA MB. 1995. Centro de Pesquisa e Conservação da Natureza Pró-Mata: termo de referência. In: BERTOLETTI JJ (Ed), Divulgação do Museu de Ciências e Tecnologia, UBEA/PUCRS, Porto Alegre: PUCRS, Porto Alegre, Brasil, p. 1-47.

BIESMEIJER JC AND SLAA EL. 2006. The structure of eusocial bee assemblages in Brazil. Apidologie 37: 240-258.

Bond-Buckup G. 2008. Biodiversidade dos Campos de Cima da Serra, Libretos, Porto Alegre, 403 p.

BURD M. 1994. Bateman's principle and plant reproduction: the role of pollen limitation in fruit and seed set. Bot Rev 60: 83-139.

CAMACHO JCB AND FRANKE LB. 2008. Efeito da polinização sobre a produção e qualidade de sementes de Adesmia latifólia. Rev Bras Sementes 30: 81-90.

CARVALHO AMC AND OLIVEIRAPEAM. 2010. Estrutura de guilda de abelhas visitantes de Matayba guinensis Aubl. (Sapindaceae) em vegetação do Cerrado. Oecol Aust 14: 40-66. 
CHARLESWORTH D. 1989. Evolution of low female fertility in plants: pollen limitation, resource allocation, and genetic load. Trends Ecol Evol 4: 289-292.

Chesson P. 1991. A need for niches? Tree 6: 26-28.

CHESSON P. 2000. Mechanisms of maintenance of species diversity. Annu Rer Ecol Syst 31: 343-366.

CHIAPPA E, RodRIGUEZ S AND BASCUÑÁN R. 2000. Preferencia y manipulacion floral de Centris rodophthalma Perez (Hymenoptera: Anthophoridae). Gayana 61: 133-138.

COCUCCI AE AND MARIATH JEA. 2004. Gametogêneses, fecundação, seleção do gametófito mais apto, embriogênese e diásporo maduro. In: FERREIRAAG AND BORGHETTI F (Eds), Germinação: do básico ao aplicado, Porto Alegre: Artmed Porto Alegre, Brasil, p.15-30.

CRUDEN RW. 1977. Pollen-ovule ratio: a conservative indicator of breeding systems in flowering plants. Evolution 31: 32-36.

CRUDEN RW. 2000. Pollen grains: why so many? Plant Syst Evol 222: 143-165.

Dick DP, Silva LB, INDA AV AND KNICKER H. 2008. Estudos comparativos da matéria orgânica de diferentes classes de solos de altitude do sul do Brasil por técnicas convencionais e espectroscópicas. Rev Bras Ciênc Solo 32: 2289-2296.

El ShafIE HAF AND Mogga JBB. 2002. Studies on the possible competition for pollen between the honey bees Apis florae (Hymenoptera, Apidae) in North-Khartoum (Sudan). J Appl Entomol 126: 557-562.

FORCONE AM AND MuÑOZ M. 2009. Floración de las especies de interés apicola en el nordeste de Santa Cruz, Argentina. Bol Soc Argent Bot 44: 393-403.

Freitas L, WolOWSKi M AND SigLiANO MI. 2010. Ocorrência de limitação polínica em plantas de Mata Atlântica. Oecol Aust 14: 251-265.

GiACOMINI HC. 2007. Os mecanismos de coexistência de espécies como vistos pela teoria ecológica. Oecol Bras 11: 521-543.

GRIFFIN SR AND BARRETT SCH. 2002. Factors affecting low seed:ovule e rations in a spring woodland herb, Trillium grandiflorum (Melanthiaceae). Int J Plant Sci 163: 581-590.

HAMRICK JL AND GODT MJ. 1990. Allozyme diversity in plant species. In: BROW AHD, KAHLER MT AND WEIR BS (Eds), Plant populations genetics, breeding and genetics resources, Sunderland: Sinauer Associates Inc., Sunderland, p. 43-63.

HoEhN P, TSCHARNTKE T, TYLIANAKIS JM AND STEFFANDEWENTER I. 2008. Functional group diversity of bee pollinators increases crop yield. Proc R Soc B 275: 2283-2291.

INOUYE DW. 2008. Effects of climate change on phenology, frost damage, and abundance of montane wildflowers. Ecology 89: 353-362.

JHA S AND VANDERMEER JH. 2009. Contrasting bee foraging in response to resource scale and local habitat management. Oikos 118: 1174-1180.

KoLB A. 2005. Reduced reproductive success and offspring survival in fragmented populations of the forest herb Phyteuma spicatum. J Ecol 93: 1226-1237.

LARCHER W. 2003. Physiological Plant Ecology, Springer, New York, 513 p.
LENNARTSSON T. 2002. Extinction thresholds and disrupted plant-pollinator interactions in fragmented plant populations. Ecology 83: 3060-3072.

LeITE AV AND MACHAdO IC. 2009. Biologia reprodutiva da "catingueira" Caesalpinia pyramidalis Tul. (Leguminosa - Caesalpinioideae), uma espécie endêmica da Caatinga. Rev Bras Bot 32: 79-88.

LouveauX J, MaUrizio A AND VORWHL G. 1978. Methods of melissopalynology. Bee World 59: 139-157.

Menezes C, Silva CI, Singer RB AND Kerr WE. 2007. Competição entre abelhas durante forrageamento em Schefflera arborícola (Hayata) Merr. Biosci J 23: 63-69.

Miotto ST AND Leitão FILHO HF. 1993. Leguminosa Faboideae gênero Adesmia DC: flora ilustrada do Rio Grande do Sul, UFRGS, Porto Alegre, 157 p.

Morgado LN, Carvalho CF, Souza B And SAntana MP. 2002. Fauna de abelhas (Hymenoptera Apoidae) nas flores de girassol Helianthus annus L. em Lavras - MG. Ciên Agrot 26: 1167-1177.

NATES-PARRA G, PAlÁcios E AND PARRA-H A. 2008. Efecto del cambio del paisaje em la estructura de la comunidad de abejas sin aguijón (Hymenoptera: Apidae) en Meta, Colombia. Rev Biol Trop 56: 1295-1308.

NAYAK KG AND DAVIDAR P. 2010. Pollinator limitation and the effect of breeding systems on plant reproduction in forest fragments. Acta Oecol 36: 191-196.

ODUM EP. 1988. Ecologia, Guanabara, Rio de Janeiro, 434 p.

Overbeck E, MÜller SC, Fidelis A, Pfadenhauer J, Pillar VD, BLANCO CC, BOLDRINI II, BOTH R AND FORNECK ED. 2007. Brazil's neglected biome: the South Brazilian Campos. Persp. Plant Ecol Evol Syst 9: 101-116.

PIANKAER .1970. On $r$ and k selection. Amer Natur 104: 592-597.

RoUBIK DW, INOVE T AND HAMID AA. 1995. Canopy foraging by two tropical honeybees: bee height fidelity and tree genetic neighborhoods. Tropics 5: 81-93.

SMITH-RAMÍREZCAND RAMÍREZKY.2010. Informe final tecnico y financero: digitalilizacion de datos de polinizadores de Chile, interacción insecto-planta y distribución de insectos, IABIN, Santiago, $23 \mathrm{p}$.

SouzA MM, PEREIRA TNS AND MARTins EM. 2002. Microsporogênese e microgametogênese associadas ao tamanho do botão floral e da antera e viabilidade polínica em maracujá-amarelo. Cienc Agrotec 26: 1209-1217.

STOCKMARR J. 1971. Tablets with spores used in absolute pollen analysis. Pollen et Spores 13: 615-621.

TAiz L And Zeiger E. 2009. Fisiologia Vegetal, Artmed, Porto Alegre, $820 \mathrm{p}$.

Tedesco SB, DALl'Agnol M, WitTMAnN-Schifino MT AND VALLS JFM. 2000. Mode of reproduction of brazilian species of Adesmia (Leguminosae). Genet Mol Boil 23: 475-478.

VAissière BE, Freitas BM AND GEMMiLl-Herren B. 2011. Protocol to detect and assess pollination deficits in crops: a handbook for its use, FAO, Rome, 70 p.

WIENS D. 1984. Ovule survivorship, broad size, life history, breeding systems and reproductive success in plant. Oecologia 6: 47-53. 
